\title{
CORRESPONDENCE
}

\section{GARNETS IN THE BORROWDALE VOLCANIC SERIES}

Str,-Dr. R. L. Oliver is to be congratulated on his two recent papers, published in this journal, in which he has convincingly demonstrated the existence of widespread welded tuffs in the Lake District and has shown that the almandine garnets were most probably " in the Borrowdale magma before its intrusion, extrusion or ejection". He states that " the evidence, suggests on balance, that the garnets are pyrogenetic". There are, however, lines of evidence which, in the writer's opinion, upset this " balance".

The principal arguments against the garnets being pyrogenetic are:-

(1) Almandine garnets have not been recorded in any modern lavas.

(2) Extreme rarity of almandines in lavas of any age, composition or history.

(3) Failure to synthesize almandine at atmospheric or moderate pressures and lack of any experimental evidence that almandine may be expected to crystallize from an andesitic magma.

(4) Absence of garnets from many lavas and tuffs of the Borrowdale Volcanic Series which are otherwise identical to those which do contain garnets.

(5) Sporadic distribution within many lava flows.

If the garnets are pyrogenetic it is to be expected that all lavas of the same composition in the same province would contain them yet this is far from the case. No garnets have been recorded by Mitchell from the Borrowdales between Shap and Coniston (Quart. Journ. Geol. Soc., 1929, 1930,1934 , and 1940), although the composition of the lavas mapped ranges from basic andesites to rhyolites and stratigraphically from bottom to the top of the succession. Indeed, there are far more lavas and tuffs in the Lake District which do not contain garnets than those which do and Dr. Oliver's contention that the very presence or absence of garnets appears to be dependent on the composition of the containing rock can be substantiated only in the areas where garnets are prolific. This distribution of garnets is most clearly seen in the district recently mapped by the writer where several garnetiferous localities occur north of the Esk in the Lower Andesites whereas only two localities are known south of the Esk in rocks of apparently the same horizon and composition. Dr. Oliver has admitted the concentration of garnets in rocks associated with the welded tuffs and this seems more important in determining the distribution of garnets than is the composition of the containing rocks. It could be that garnets are restricted to those volcanoes which produced welded tuffs although in the absence of detailed knowledge of the distribution of welded tuffs this cannot be proved.

If the garnets did not crystallize from the magma but were nevertheless contained in it before extrusion, the only reasonable possibility is that they were xenocrysts. Corroded garnets and coronas of early formed plagioclase around garnets are consistent with the concept of xenocrystal garnets in disequilibrium with the liquid and around which the first minerals crystallized. If the garnets were free to react with the liquid they might be expected to vary in composition sympathetically with the composition of the containing rock whether they were of pyrogenetic origin or xenocrysts. In the writer's experience garnets are often very localized within one flow occurring in patches reminiscent of partially disintegrated xenoliths. Whilst it is admitted that a more even distribution does occur in some flows, if the garnets crystallized out of the "Borrowdale" magma a regular distribution is to be expected in all flows.

The origin of garnet xenocrysts is puzzling but almandine garnets do occur near the contacts of basic igneous intrusions and argillaceous sediments as at Carrock Fell. Almandine garnets would probably form in the Skiddaw 
Slates in the walls of the magma reservoirs and vents and would be incorporated into the magma only in conditions of excess gas pressures such as might occur during periods of welded tuff formation.

Department of Geology,

R. J. Firman. 19 th June, 1956.

UNIVERSITY OF NOTTINGHAM.

\section{NEW NAME FOR LIAS AMMONITE}

SIR,-Prof. R. Trümpy, of Zürich, has kindly called my attention to the fact that my Blue Lias ammonite, species, Psiloceras (Caloceras) multicostatum Donovan, 1952, p. 638, is homonymous with Psiloceras (Caloceras) multicostatum Brandes, 1912, p. 431, proposed for Quenstedt, 1883, pl. 1, fig. 12. I therefore propose Psiloceras (Caloceras) bloomfieldense nom. nov. for $P$. (C.) multicostatum Donovan, 1952, non Brandes, 1912, holotype to be the same specimen as for my earlier species, namely Geological Survey Museum no. 85017. The specific name is derived from Bloomfield Quarry, Farmborough, Somerset, the type locality.

\section{REFERENCES}

Brandes, T. 1912. Die faziellen Verhältnisse des Lias zwischen Harz und Egge-Gebirge mit einer Revision seiner Gliederung, Neues Jahrb. Min., Beil.-Bd. xxxiii, 325-508.

Donovan, D. T. 1952. The Ammonites of the Blue Lias of the Bristol District, Part I, Psiloceratidae and Schlotheimidae, Ann. Mag. Nat. Hist., ser. 12, v, 629-655.

QUENSTEDT, F. A. 1883. Die Ammoniten des Schwäbischen Jura. Bd. I, part 1, Stuttgart.

Geology Department, D. T. Donovan.

THE UNIVERSITY,

BRISTOL, 8.

1 st August, 1956.

\section{THE BOUNDARY BETWEEN MIDDLE AND UPPER JURASSIC}

SIR,-Dr. Arkell's new book, Jurassic Geology of the World (1956), is a masterpiece in conception and execution, and all students of the Jurassic system will be indebted to his immense labours and to his clarity of exposition and synthesis, as well as to the publishers for a style of production worthy of this majestic undertaking. In a book where almost every detail and generalization is based on fact or common sense, it is all the more disturbing to find a statement that alters all established usage in Jurassic stratigraphy, and this without a word of satisfactory explanation or supporting stratigraphical evidence.

This statement is the inclusion of the Callovian stage in the Middle Jurassic (p. 8), a step taken, apparently, only so that the table of stages and zones on p. 7 may look neater, and in order to conform with the " priority" of von Buch's arrangement of 1839 . It is quite inconsistent with the author's stated preference for " a compromise between priority, suitability and usage" (p. 8) and with his rejection (p. 7) of " ancient terms and meanings of before 1850 "; in fact, from its very date, it cannot have been a grouping of stages or zones within the author's self-imposed terms of reference. As for priority, von Buch's scheme is inconsistent with that proposed in England by Conybeare and Phillips in 1822 . It was, moreover, Oppel's considered opinion (1858, p. 821) that it should be replaced in England, France, and South-West Germany by a modified version of Conybeare and Phillips's scheme, which had been widely used up to that time and has been universally used ever since. 